\title{
POTENTIALLY TOXIC ELEMENTS IN SOILS AND PLANTS ON A RECLAIMED COAL- WASTE DUMP IN SOUTHERN POLAND (PRELIMINARY STUDY)
}

\author{
Weronika NADLONEK and Jerzy CABALA *
}

University of Silesia, Faculty of Earth Sciences, 41-200 Sosnowiec, 60 Bedzinska Str, Poland

*Corresponding author's e-mail: jerzy.cabala@us.edu.pl

\begin{tabular}{l} 
ARTICLE INFO \\
\hline Article history: \\
Received 5 October 2015 \\
Accepted 14 March 2016 \\
Available 5 May 2016 \\
\hline
\end{tabular}

\section{Keywords:}

Heavy metals

Autoignition phenomena

Soil mineral composition

Reclamation material

USCB

\begin{abstract}
The phase composition and concentrations of six potentially toxic elements $(\mathrm{Zn}, \mathrm{Pb}, \mathrm{Mn}, \mathrm{Cu}, \mathrm{Ni}$, and $\mathrm{Cd}$ ) in topsoil and plants were studied. The samples were taken from the waste dump in Katowice in the Upper Silesian Coal Basin. Mineral matter was identified by XRD and SEM. Mineral composition of studied topsoils depends on material composition used to forming the surface layer on the dump. There aluminosilicates (chlorite, muscovite, clays minerals), quartz, $\mathrm{Fe}$ and $\mathrm{Ca}$ sulphates and Fe oxides dominate. On plants shoots there were identified dolomites, $\mathrm{Fe}$ oxides, $\mathrm{Ca}$ sulphates, $\mathrm{Na}$ and $\mathrm{K}$ chlorides and rarely $\mathrm{Au}-\mathrm{Cu}$ alloys beside quartz and aluminosilicates.

By using AAS and ICP-OES contents of heavy metals in soils and plants were determined. Scanning electron microscope allowed to define the chemical composition in soils and plants and $\mathrm{XRD}$ to identify mineral contents. In this work measurement of $\mathrm{pH}$ and total organic carbon content were carried out. Results indicate that topsoil is highly enriched in heavy metals, especially in zinc, and it is positive correlated with contents of metals in plants growing on such contaminated area. In soils $\mathrm{Zn}$ content was in the range from 120 to $3550 \mathrm{mg} \mathrm{kg}^{-1}, \mathrm{~Pb}$ from 31 to $905 \mathrm{mg} \mathrm{kg}^{-1}$, Ni from 3 to $78 \mathrm{mg} \mathrm{kg}^{-1}$ and $\mathrm{Cd}$ from 1 to $11 \mathrm{mg} \mathrm{kg}^{-1}$. For plants it was respectively $\mathrm{Zn}$ to $284 \mathrm{mg} \mathrm{kg}^{-1}, \mathrm{~Pb}$ to $59 \mathrm{mg} \mathrm{kg}^{-1}$, Ni to $4 \mathrm{mg} \mathrm{kg}^{-1}$ and $\mathrm{Cd}$ to $1 \mathrm{mg} \mathrm{kg}^{-1}$. The results indicate that application of coal wastes as reclamation material is not advised due to environmental issues.
\end{abstract}

\section{INTRODUCTION}

Waste from mining, steel and the chemical industry are very important for the environment in highly-urbanized areas that are also heavily industrialized. Many cities in the Upper Silesian Coal Basin (USCB, southern Poland) have a rich industrial history primarily related to $\mathrm{Pb}-\mathrm{Ag}-\mathrm{Fe}$ mining and, over the last 200 years, to coal and zinc mining. At present, 26 mines exploit coal by underground methods in this region. In the USCB, there are numerous large dumps of coal wastes and coalcombustion products, e.g., fly ash. In areas where the mining of metal ores or coal is developed, different kinds of mine waste are commonly used as raw material for reclamation works. As a consequence, new environmental problems are generated, e.g., air-, water- and soil contamination that arises from chemical changes of organic matter resulting from self-heating.

Waste dumps are investigated in regard to the thermal changes occurring in them (Misz-Kennan and Fabiańska 2010; Fabiańska et al., 2013) and from the perspective of coal-waste use (Galos and Szlugaj, 2014). Similar problems related to fires in coal waste rich in organic matter and subsequent environmental contamination occur in many places all over the world, e.g., in China, Venezuela, India, Indonesia and USA (Stracher et al., 2015). Heating of organic matter causes geochemical- and mineralogical changes, particularly those which can influence the geochemical activation of some heavy metals (HM). To identify reasons processes influencing HM activation, it is particularly important to know the nature of the mineral-phase transformations and the geochemistry of the related environment. An increase in heavy-metal activity very often leads to their concentration in biotic systems. A consequence of the activation of some heavy metals, metalloids, and other trace elements is their migration to the trophic chains (Cui et al., 2011). The concentration of heavy metals in plants plays a really important role (KabataPendias, 2001; Nagajyoti et al., 2010). These problems have been studied in the Silesian-Cracovian area on waste derived from the mining and smelting of zinc and lead (Cabala et al., 2013; Jerzykowska et al., 2014). Coal mine waste deposited in many places in the Silesian-Cracovian region are sources of waterand soil contamination by $\mathrm{SO}_{4}{ }^{2-}, \mathrm{Cl}^{-}$ions and elements such as $\mathrm{As}, \mathrm{Ba}, \mathrm{Cu}, \mathrm{Co}, \mathrm{Cr}, \mathrm{Ni}, \mathrm{Mo}, \mathrm{Zn}, \mathrm{Fe}, \mathrm{Pb}, \mathrm{Sr}$ and $\mathrm{V}$ (Ciesielczuk et al., 2014).

The aim of the study was to establish the concentration of selected potentially-toxic metals $(\mathrm{Cd}$, 


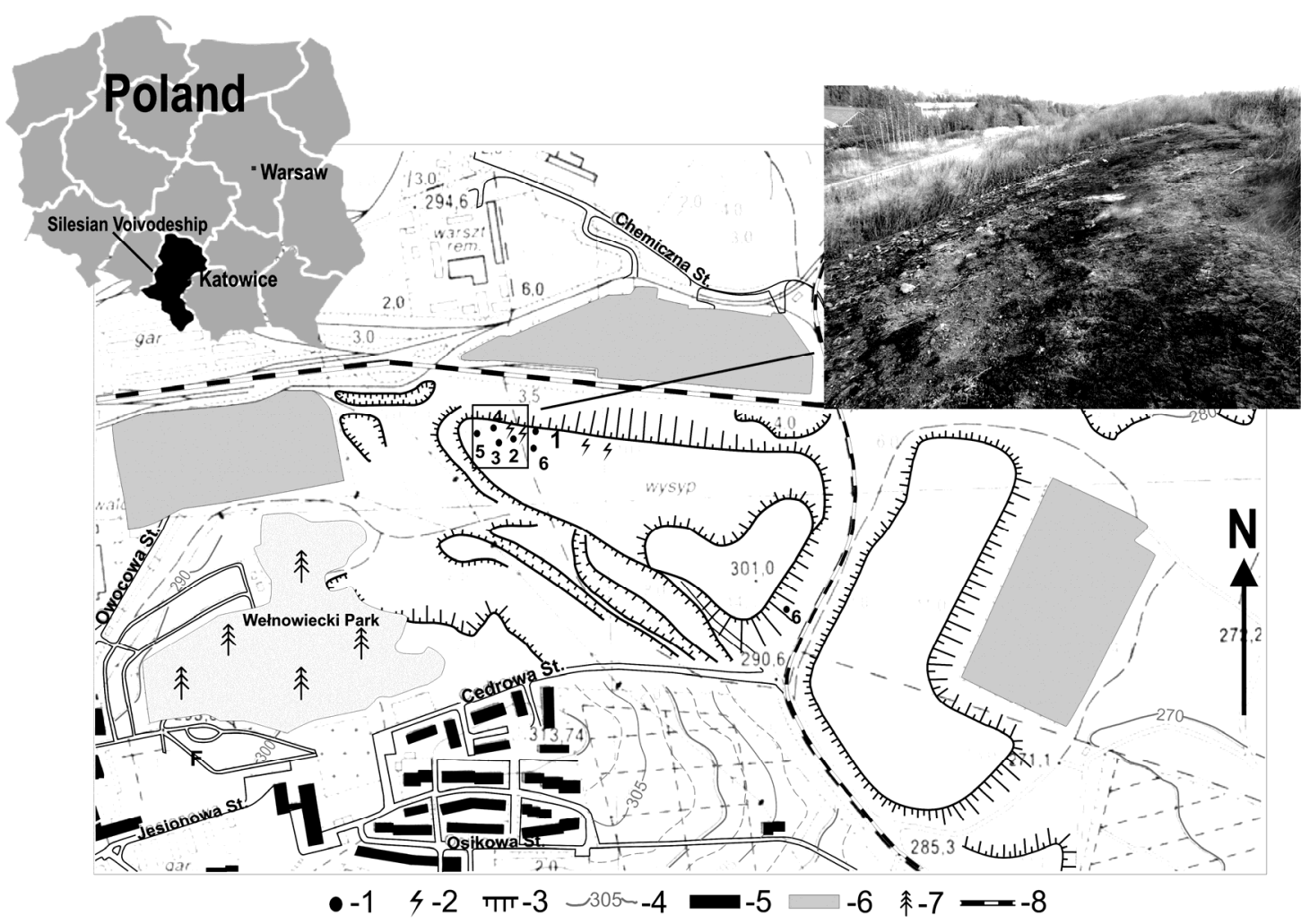

Fig. 1 Sampling sites. The same points are marked for plants (P) and soils (S). Explanation: 1- sampling sites, 2- self-heating sites, 3-scarps, 4 - isohypse, 5- residential buildings, 6- industrial area, 7- forest area, 8- railway tracks.

$\mathrm{Cu}, \mathrm{Mn}, \mathrm{Ni}, \mathrm{Pb}, \mathrm{Zn}$ ) originating from the reclaimed waste dump in Katowice-Wełnowiec in topsoil and in different plant organs and to define possible relationship between contents of elements in soil and on leaf surfaces, inflorescences or stems. The passive emission of submicroscopic mineral phases on plants was used to evaluate the quality of the environment. This work should allow the estimation of heavy-metal transfer from soil to biotic systems.

\section{LOCATION AND GEOLOGICAL SETTING OF THE AREA STUDIED}

The analyzed material was collected from an inactive municipal waste dump in Katowice city, southern Poland (Fig. 1).

The waste dump covers 16 hectares and was formed on Pleistocene sands and Carboniferous deposits (Upper Missisipian) which, in the Katowice region, belong to a tectonic unit called the Main Anticline. The latter are sandstones, shales and conglomerates with layers of hard coal. Pleistocene fluvial sandstones occur in the immediate basement of the dump. Between 1991-1996, a waste dump was developed in a depression in this area. About 1.6 million tonnes of wastes from hard-coal mining $(22.5 \%)$, municipal waste $(21.5 \%)$, building rubble (40\%) and waste from a composting plant were banked there (Klejnowska, 1996).

The waste dump was reclaimed in 1998 using Mississippian coal-mine waste mainly composed of clay shales, mudstones, sandstones and hard coal
(5-15\%), sometimes containing $\mathrm{Ca}, \mathrm{Ca}-\mathrm{Mg}, \mathrm{Fe}$ carbonates and $\mathrm{Fe}$ sulphides. Mineralogy and petrography of Missisippian rocks were described by Ciesielczuk et al. (2014) and Fabiańska et al. (2013)

The presence of organic matter in the material used in the reclamation led to endogenic thermal events. The coals from USCB mainly contain the vitrinite group macerals. The proportion of vitrinite generally increases from $40 \%$ to $80 \%$ westwards. The inertinite group amounts to $10-50 \%$, with a tendency of increase northwards and eastwards. Liptinite macerals rarely exceed $15 \%$ and vanish with increasing depth (Kędzior and Jelonek, 2013). Macerals from the vitrinite group are especially prone to self-heating (Taylor et al., 1998).

The projected total thickness of the reclaimed layer (Klejnowska, 1996) was 2.2 meters consisting of the following layers: reclaimed, drainage, protection, sealing, support and 0.4 meters hummus layer.

From the year 2001, biogas (methane) was exploited using a system of tens of degassing wells. Autoignition phenomena were observed from the year 2007 to 2014. Surface temperatures have reached to $59{ }^{\circ} \mathrm{C}$ and, at a depth of 0.3 meters, to $460{ }^{\circ} \mathrm{C}$ (Ciesielczuk et al., 2011).

The waste dump lies in a highly developed industrial region where the high emission of dusts derived from different sources has an essential influence on contamination of the top layer. The Upper Silesian Industrial Region is characterized by high values of emissions (dust and gases) from coal 
combustion, steel production and the chemical industry. Dust emission on an area comprising $1 \mathrm{~km}^{2}$ has amounted to 0.9 tons. Values of suspended dust PM2.5 have exceeded, by $8-12 \mu \mathrm{g} / \mathrm{m}^{3}$, an allowable limit of $27 \mu \mathrm{g} / \mathrm{m}^{3}$. Similarly, average dust PM10 concentrations have exceeded, by $5-17 \mu \mathrm{g} / \mathrm{m}^{3}$, a limit of $40 \mu \mathrm{g} / \mathrm{m}^{3}$ designated for the Upper Silesian agglomeration. The frequency of overruns in the 24hour allowable concentration limit of suspended dust PM10 has been up to three times greater than that allowed (Szczygieł et al., 2013).

\section{MATERIAL AND METHODS}

Two types of samples were collected, namely, soil and plant material. Different species of plants and the topsoil layer (depth 0-30 centimeters) were the research material. The following plant species were identified: Amaranthus retroflexus, Artemisia vulgaris, Erigeron canadensis, Sisymbrium loeselii and Cucurbita pepo.

At sites of spontaneous combustion, plants do not grow. In places close to these sites, mosses and vascular plants can be seen. Here, apart from researched species, the following were recognized: Erigeron annuss, Datura stramonium, Lycopersicon esculentum and moss. Wider studies enabled identification of species such as Achillea millefolium, Artriplex nitens, Chenopodium album, Cirsium arvense, Daucus carota, Matricaria inodora, Picris hieracioides, Sonchus arvensis, Sonchus Asper, Tussilago farfara and Verbascum Thapsus (Ciesielczuk et al., 2011).

Soil samples were collected at six points (S1-S6) and sieved into two fractions, i.e., the finest $<0.71 \mu \mathrm{m}$ (samples S1/1-S6/1) and the coarsest $>500 \mu \mathrm{m}$ (S1/2$\mathrm{S} 6 / 2$ ). The weight of soil samples was about 1 kilogramme.

Soil mineral matter was examined using X-ray Diffraction (XRD). Mineral composition was identified using an X'Pert PANalytical PRO PW 3040/60 Diffractometer. Range of analyses was from 2.50 to $64.98^{\circ} 2 \theta$, step size $0.008^{\circ} 2 \theta$ and scan step size equaled $300 \mathrm{~s}$. The radiation used was $\mathrm{CuK}_{\alpha}$ $(1.5406 \AA)$ and the current parameters were $30 \mathrm{~mA}$ and $40 \mathrm{kV}$.

For the Scanning Electron Microscope (SEM) investigation, a Philips XL30 ESEM/TMP with EDAX analyzer was used. Soil and plant samples (root, stem, leaf, and flower) were applied to carbon tape having dimensions of $9 \mathrm{~mm} \times 15 \mathrm{~mm}$. The accelerating voltage was $15 \mathrm{kV}$ and the current was $20 \mathrm{nA}$. The research was carried out in the environmental, low vacuum mode (0.3 Torr). Images were obtained with the Back Scattered Electron (BSE) detector. 120 BSE images were made. Micro chemical analysis EDS spectra were processed using Philips software.

Trace element ( $\mathrm{Cd}, \mathrm{Cu}, \mathrm{Mn}, \mathrm{Ni}, \mathrm{Pb}, \mathrm{Zn})$ contents in samples $\mathrm{S} 1 / 1$ - S6/1 and $\mathrm{S} 1 / 2$ - S6/2 were determined by Atomic Absorption Spectrometry
(AAS) using a SOLAAR M6 spectrometer. The sieved soil and plant samples were combusted at a temperature of $500{ }^{\circ} \mathrm{C}$ and ground in the agate mortar. Weighted samples $(\sim 0.1 \mathrm{~g})$ were mineralized in hydrofluoric $\left(5 \mathrm{~cm}^{3}\right)$ and nitric acid $\left(1 \mathrm{~cm}^{3}\right)$ in open vessels. After digestion, the residue was transferred in solution into flasks and filled to $25 \mathrm{~cm}^{3}$ with demineralised water. Samples S1-S6 were investigated by inductively coupled plasma optical emission spectroscopy using an iCAP6500 DUO spectrometer. Samples were dried at room temperature and passed through $2 \mathrm{~mm}$-mesh nylon sieves before being ground in a ball mill to $<0.06 \mathrm{~mm}$. Samples were dissolved in chloroazotic acid (1 gram of the sample in $6 \mathrm{~cm}^{3}$ of $\mathrm{HCl}$ and $2 \mathrm{~cm}^{3}$ of $\left.\mathrm{HNO}_{3}\right)$ and left for one night before being heated for one hour in aluminum heating blocks at $95{ }^{\circ} \mathrm{C}$. Cooled-down solutions were filtered into polypropylene bottles and filled with deionized water to $50 \mathrm{~cm}^{3}$.

Soil reaction (S1-S6) was measured by the potentiometric method in a water suspension 1:5 (m/V) using a Slandi $\mathrm{pH}$ meter SP300. The suspension reaction was measured on the day after the samples were prepared. Two calibration solutions of pH 4.00 and $\mathrm{pH} 7.00$ were used.

Total organic carbon (TOC) was analysed by the coulometry-titration method. A Strohlein COULOMAT 702 was used. The samples were combusted in an oxygen atmosphere at $1300{ }^{\circ} \mathrm{C}$ after carbonates had been removed. The carbon dioxide formed was titrated by barium perchlorate.

All analyses were carried out in the Faculty of Earth Sciences, University of Silesia, Sosnowiec, Poland.

\section{RESULTS}

\subsection{MINERAL MATTER IN TOPSOIL}

The investigated topsoils consist mainly of quartz, the aluminosilicates kaolinite, illite, chlorites and muscovite, the carbonates calcite, dolomite and ankerite, the sulphate gypsum and native sulphur (Fig. 2). The most common carbonates are calcite and dolomite. Crystals of gypsum were often recognized. The presence of native sulphur is characteristic.

Microscopic investigations enabled the identification of metal-bearing grains commonly ranging in dimension from $<1-50 \mu \mathrm{m}$ on plants and $<1500 \mu \mathrm{m}$ in the soils. Organic matter (Figs. 3a, c, f) occurs in an association with quartz and aluminosilicates, commonly as polymineralic aggregates in soil. Aluminosilicates (Figs. 3b, d, f) were identified by their characteristic EDS spectra (Fig. 4a), and by $\mathrm{XRD}$, as muscovite, biotite, kaolinite and illite (Table 1). Quartz occurs as irregular and/or oval grains ranging in size from 1-500 $\mu \mathrm{m}$ (Figs. 3a, b).

Gypsum occurs in as isometric forms (Fig. 3c) or as elongated, acicular crystals up to $200 \mu \mathrm{m}$ in length (Fig. 3e). Iron sulphates occur as small $(<1 \mathrm{~mm})$ grains (Figs. 3a, 4b) dispersed in polymineralic aluminosilicate aggregates rich in organic matter. Native 


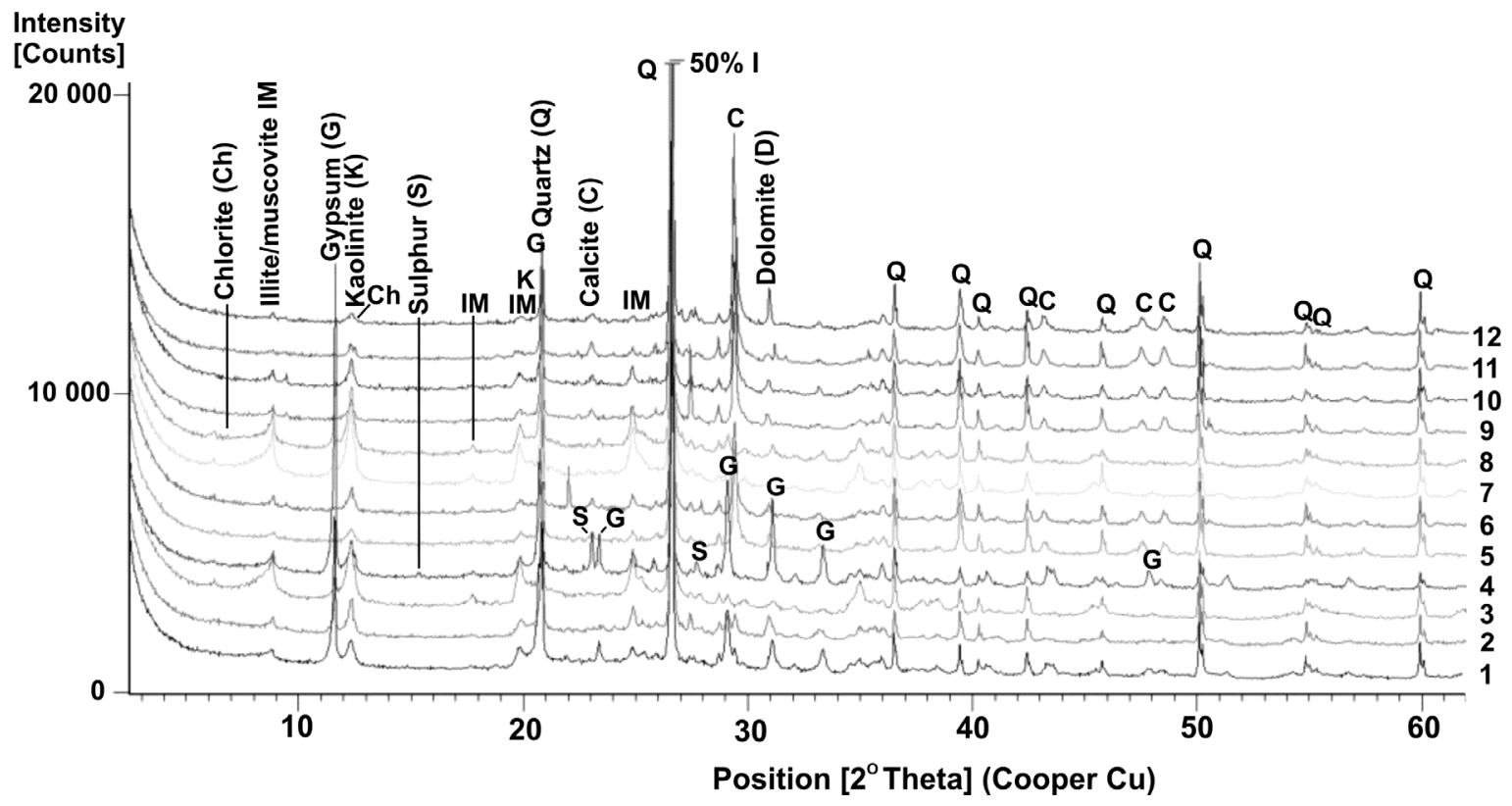

Fig. 2 XRD spectra of topsoil samples $1 \ldots 12$; 1-S1/2-fraction $>500 \mu \mathrm{m}, \quad 2$-S1/1-fraction $<0.71 \mu \mathrm{m}$, 3-S2/2- fraction $>500 \mu \mathrm{m}, 4$-S $2 / 1$ - fraction $<0.71 \mu \mathrm{m}, 5$ - S3/2-fraction $>500 \mu \mathrm{m}, 6-\mathrm{S} 3 / 1$-fraction $<0.71 \mu \mathrm{m}$, 7- S4/2-fraction $>500 \mu \mathrm{m}, 8-\mathrm{S} 4 / 1$ - fraction $<0.71 \mu \mathrm{m}, 9-\mathrm{S} 5 / 2$ - fraction $>500 \mu \mathrm{m}$, 10-S5/1-fraction $<0.71 \mu \mathrm{m}, 11$-S6/2-fraction $>500 \mu \mathrm{m}, 12-\mathrm{S} 6 / 1$ - fraction $<0.71 \mu \mathrm{m}$.

sulphur (Figs. 3d, 4c) is ever present. Euhedral barite crystals $<30 \mu \mathrm{m}$ in size were noted (Fig. 3b).

Native sulphur occurs as large $(\sim 100 \mu \mathrm{m})$ aggregates of small $(2-5 \mathrm{~mm})$ crystals with a dense network of fractures (Figs. 3d, 3d'). Their surfaces show traces of dissolution with many microcaverns. Iron oxides commonly form microporous aggregates (Fig. 3c). Individual spherical forms of $\mathrm{Fe}$ oxides $(<90 \mu \mathrm{m})$ also occur. In some instances, aluminosilicate spherules occur inside a thin Fe-oxide crust (Fig. 3c'). Aluminosilicate spheres, probably fly ash, more typically occur as characteristic spherical forms in botryoidal aggregations sizes of $0.1 \mu \mathrm{m}$ to $20 \mu \mathrm{m}$ (Fig. 3f) reminding thin shells with distinctive microapertures. Aggregates rich in $\mathrm{Pb}$ and $\mathrm{Zn}$ contain submicroscopic $(<1 \mu \mathrm{m})$ grains of $\mathrm{Pb}$ sulphide, $\mathrm{Zn}$ sulphide or $\mathrm{Zn}$ and $\mathrm{Pb}$ carbonates (Fig. 4d). $\mathrm{Pb}$ sulphide is dispersed in aggregates of aluminosilicates (illite, kaolinite, muscovite and chlorite), and accompanying gypsum crystals (Fig. 3e).

Based on BSE/EDS analysis of images, phases in the soil can be grouped as follows:

1. Major minerals: Aluminosilicates, illite, quartz, $\mathrm{Ca}$ carbonate, $\mathrm{Ca}$ sulphate, Fe sulphate, Fe oxide, $\mathrm{C}_{\text {org }}$ aggregates.

2. Minor minerals: Barite, Fe hydroxide, dolomite, Fe sulphide, $\mathrm{Pb}$ sulphide, native sulphur.

3. Accessory minerals: Zircon, Ti- and $\mathrm{Zn}$ oxides, Ca phosphate, $\mathrm{Zn}$ sulphate, Au-Cu alloys.

At combustion sites, various mineral associations are characteristic, e.g., quartz - organic matter - Fe sulphates (Fig. 3a), quartz aluminosilicates - barite (Fig. 3b), aluminosilicates native sulphur (Fig. 3d), aluminosilicates - gypsum (Fig. 3e).

\subsection{MINERAL MATER IN PLANTS}

On the roots and shoots of Sisymbrium loeselii and Erigeron Canadensis, minerals were identified that also occur in the soils. Very small $(<20 \mu \mathrm{m})$ quartz grains occur not only in rhizodermis, but also on stems and leaf cavities also. Significant quantities of silica occur in leaves (Table 1; Fig. 5a). Silica is incorporated into the leaf structure of $E$. canadensis. It forms oval aggregations $(10-300 \mu \mathrm{m})$ within which stomas are very clearly visible. In rhizodermis, aluminosilicates were identified most often, in some cases with zinc sulphide present in their structure (Fig. 5b). Small grains of barite were noted (Figs. 5b, 4e). Ca- and $\mathrm{Mg}$ carbonates, and Fe oxides/hydroxides with $\mathrm{Zn}$ sulphide also occur (Fig. 5c). Similar phases were identified on flowers (Table 1). On stems and leaves, it was mainly submicroscopic grains of quartz, $\mathrm{Fe}$ oxides and aluminosilicates that were noted. Aluminosilicates may occur in spherical forms $(<10 \mu \mathrm{m})$ were seen. The presence of $\mathrm{Ca}$ sulphates and $\mathrm{Na}, \mathrm{K}$ salts is interesting because it indicates forming of unstable phases which are sulphates and $\mathrm{Na}, \mathrm{K}$ chlorides (Table 1; Fig. 4f). Na- and $\mathrm{K}$ salts occur as crystalline cubic forms $(<5 \mu \mathrm{m})$ and Ca sulphates as elongated crystals $<10 \mu \mathrm{m}$ in size. Unusual ( $\mathrm{Au}-\mathrm{Cu})$, ( $\mathrm{Au}-\mathrm{Cu}-\mathrm{Ag})$ and $(\mathrm{Pb}-\mathrm{Sn})$ phases were identified as small $(<10 \mu \mathrm{m})$ entities on roots, leaves and flower surfaces (Fig. 5d). Iron oxides $(<25 \mu \mathrm{m})$ are characterized by irregular forms (Fig. 5c), and carbonates by tabular and prismatic forms (Fig. 5c).

\subsection{ELEMENT CONCENTRATIONS}

In topsoil, especially high total contents for $\mathrm{Zn}$ $\left(<1982 \mathrm{mg} \mathrm{kg}^{-1}\right)$ and $\mathrm{Pb}\left(<739 \mathrm{mg} \mathrm{kg}^{-1}\right)$ were 

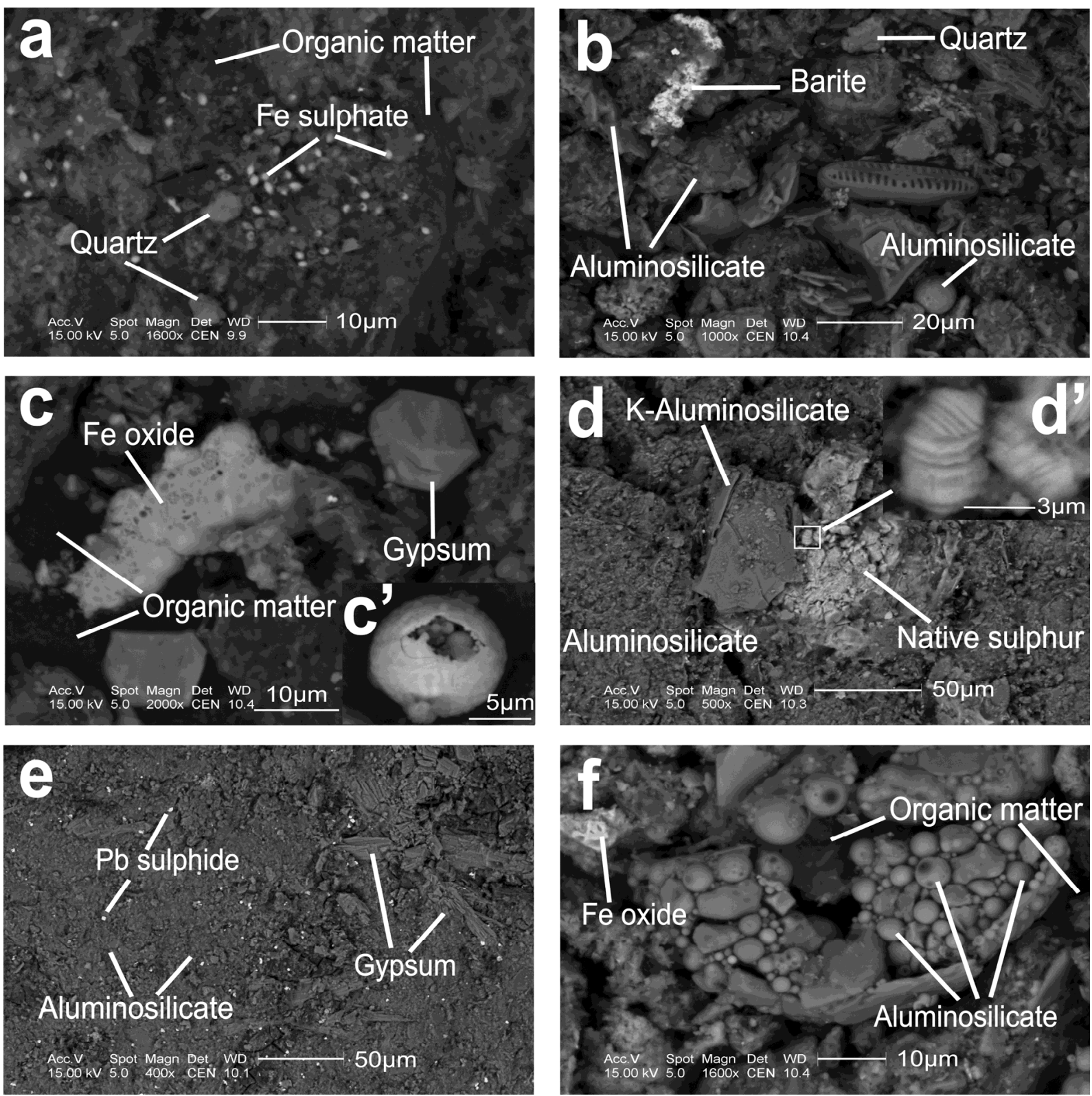

Fig. 3 BSE images: a- topsoil near the self-heating site S2, b- topsoil near the self-heating site S2, c- topsoil near the self-heating site S2, c'- spherical Fe oxide with aluminosilicate inside, $\mathrm{d}$ - topsoil $12 \mathrm{~m}$ from the self-heating site S4, d'- magnification of native sulphur, e- topsoil $12 \mathrm{~m}$ from the self-heating site S4, f- topsoil $350 \mathrm{~m}$ from the self-heating site S6.

determined (Table 2). Considerably higher concentrations of these metals were measured in fine-grained $(<0.71 \mu \mathrm{m})$ fractions, namely $<3550 \mathrm{mg} \mathrm{kg}^{-1}$ for $\mathrm{Zn}$ and $<905 \mathrm{mg} \mathrm{kg}^{-1}$ for $\mathrm{Pb}$. Manganese concentrations in the range $73-527 \mathrm{mg} \mathrm{kg}^{-1}$ are relatively low. Copper and nickel concentrations are not especially high at $<323 \mathrm{mg} \mathrm{kg}^{-1}$ and $\mathrm{Ni}<8 \mathrm{mg} \mathrm{kg}^{-1}$, respectively Cadmium concentrations vary from $1-8 \mathrm{mg} \mathrm{kg}^{-1}$ (Table 2), with its highest concentrations in finegrained $<0.71 \mu \mathrm{m}$ ) fractions.

In plants, $\mathrm{Zn}$ showed high contents of $<284 \mathrm{mg} \mathrm{kg}^{-1}$ (PAr5/root) and $\mathrm{Pb}$ contents of $<59 \mathrm{mg} \mathrm{kg}^{-1}$ (PAr5/root). Concentrations of $\mathrm{Mn}$ are low at $<65 \mathrm{mg} \mathrm{kg}^{-1}$ (PS1/root; Table 2). Copper and $\mathrm{Ni}$ contents are rather low, varying from $4 \mathrm{mg} \mathrm{kg}^{-1}$ (PS1/leaf) to $50 \mathrm{mg} \mathrm{kg}^{-1}$ (PAr5/root) for $\mathrm{Cu}$ and from $<1 \mathrm{mg} \mathrm{kg}^{-1}$ (PC/seed; PS1/leaf) to $4 \mathrm{mg} \mathrm{kg}^{-1}$ (PE4/root; PAr5/root; PS6/root) for Ni. In Sisymbrium loeselii, there are clearly higher concentrations of heavy metals in roots compared to shoots (Table 2).

Soil reaction is in the range from 3.74 (S4)8.02 (S6). Samples S1, S2, and S4 have an acidic reaction, and $\mathrm{S} 3, \mathrm{~S} 5, \mathrm{~S} 6$ an alkaline reaction. Between the S1 and S5 sampling sites located about $50 \mathrm{~m}$ apart, a significant difference in $\mathrm{pH}(\Delta \mathrm{pH}=3.8)$ was noted.

Total organic carbon contents of soil (TOC) vary from $6.58-16.2 \%$. The highest content occurs in sample S4, the lowest in S1. The average TOC content in samples S2-S6 is $13.2 \mathrm{wt} \%$. Sample S4 with the highest TOC content is also the most acidic (pH 3.74). 
a

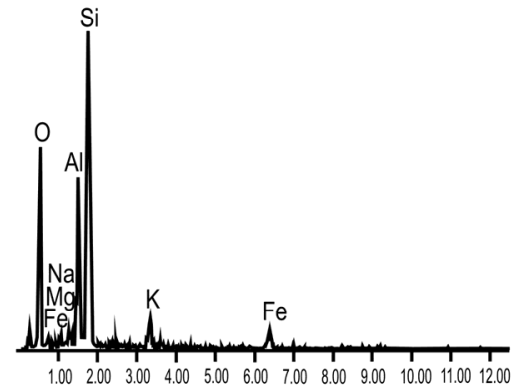

d

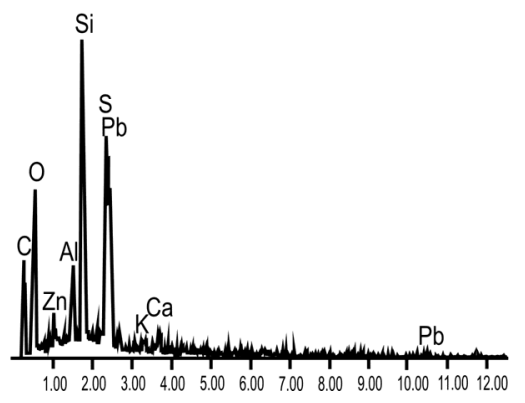

b

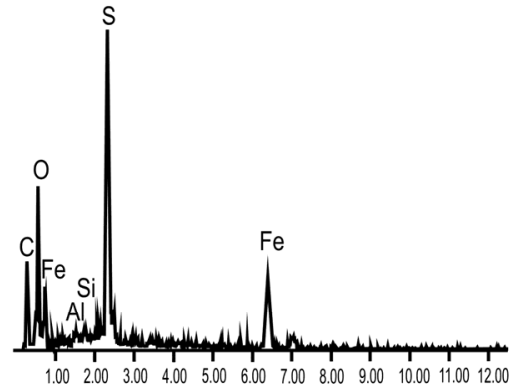

e

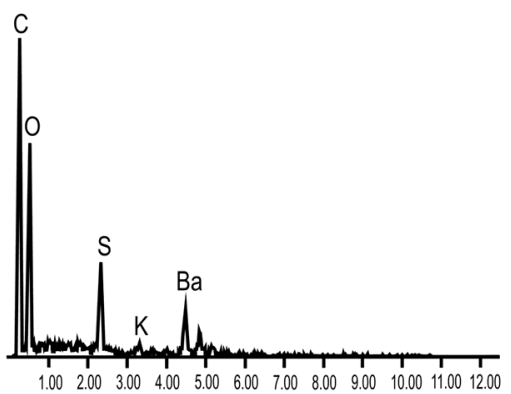

C

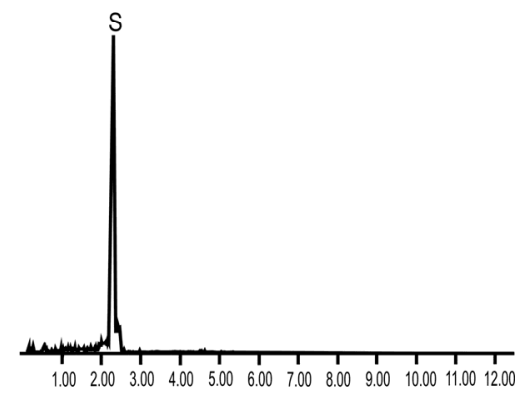

$f$

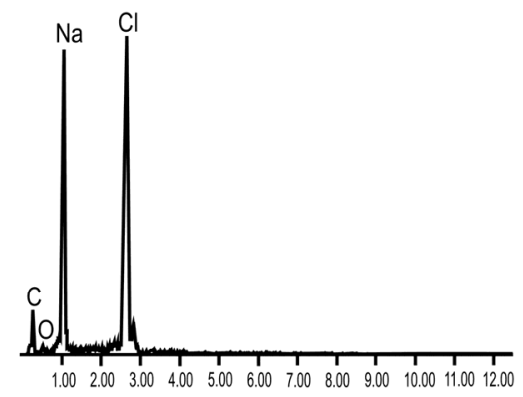

Fig. 4 EDS spectra : a- soil S2, b- S2, c- S4, d- S6, e- root of Sisymbrium loeselii collected from S1 site, f- leaf of Sisymbrium loeselii collected from S1 site.
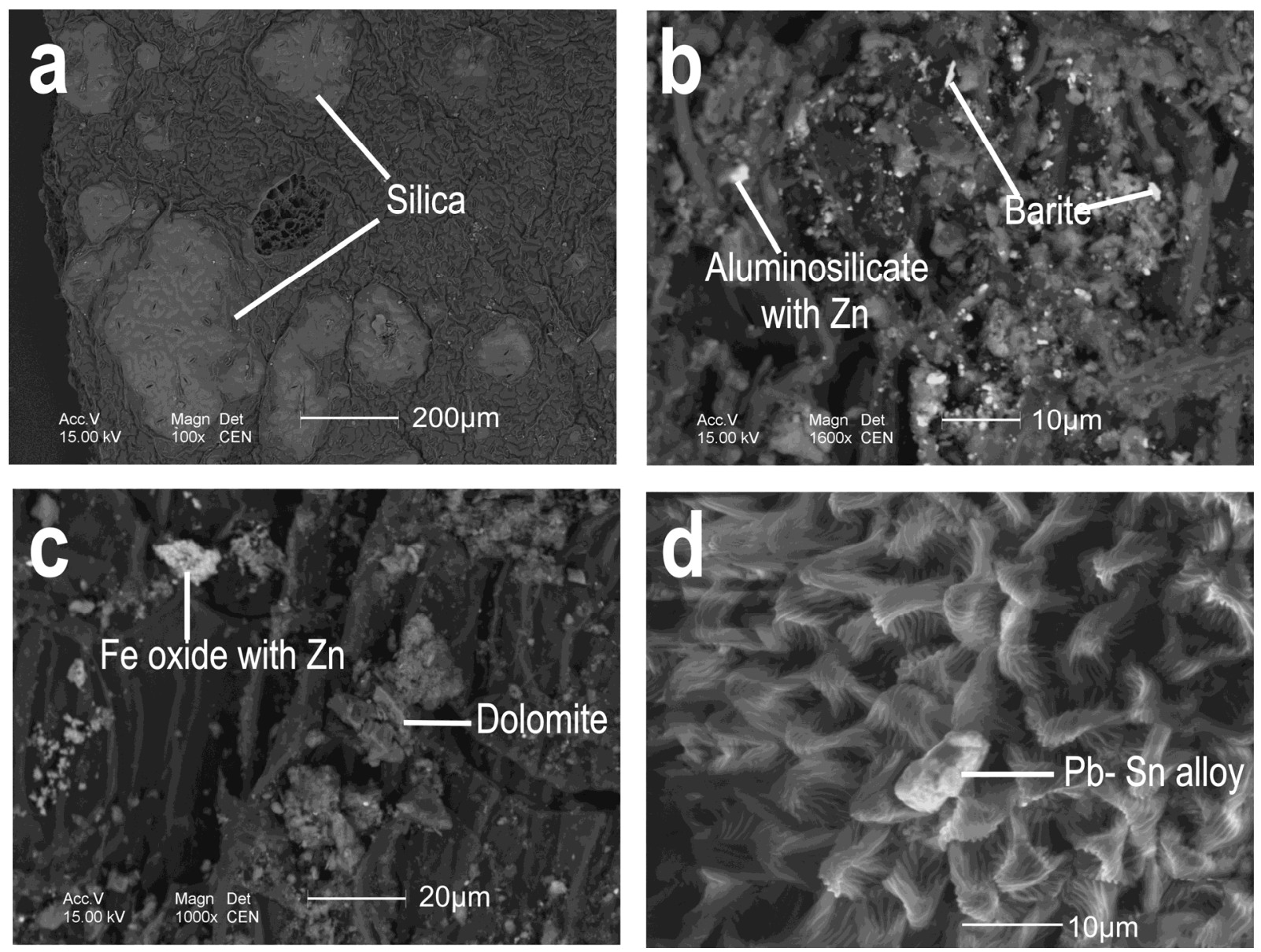

Fig. 5 BSE images: a- leaf of Erigeron Canadensis collected from S1 site, b- root of Erigeron Canadensis collected from S1 site, c- root of Erigeron Canadensis collected from S1 site, d- flower of Sisymbrium loeselii collected from S1 site. 
Table 1 Phases identified by SEM and EDS analyses (\% wt.)

+++: dominant component $>10 \%$, ++: between $10 \%$ and $3 \%$, + : between $3 \%$ and $1 \%$, I: trace content.

\begin{tabular}{|c|c|c|}
\hline \multicolumn{2}{|r|}{ Analyzed material } & Minerals groups and minerals \\
\hline \multicolumn{2}{|r|}{$\begin{array}{c}\text { Topsoil }(0-30 \mathrm{~cm}) \\
\text { S2 }\end{array}$} & $\begin{array}{l}\text { Ca sulphate +++; Fe sulphate +++ } \\
\text { Fe oxide ++; Native sulphur ++, } C_{\text {org }} \text { aggregate ++ } \\
\text { Quartz +; Barite +; Fe sulphide +; Chlorite +; Illite +; } \\
\text { Aluminosilicate +; Muscovite + } \\
\text { Fe hydroxide with S i P I }\end{array}$ \\
\hline \multicolumn{2}{|r|}{$\begin{array}{c}\text { Topsoil }(0-30 \mathrm{~cm}) \\
\text { S4 }\end{array}$} & $\begin{array}{l}\text { Ca sulphate }+++ \\
\text { Illite ++; Native sulphur ++; } \mathrm{C}_{\text {org }} \text { aggregate }++ \\
\text { Quartz +; Barite +; Pb sulphide +; Fe hydroxide +; } \\
\text { Aluminosilicate +; Kaolinite +; Fe oxide + } \\
\text { Muscovite I; Zirconium I; Fe sulphate I; Fe sulphide; } \\
\text { Biotite I; Ti, Zn oxide I; Cu, Fe sulphate I; Au-Cu alloys I }\end{array}$ \\
\hline \multicolumn{2}{|r|}{$\begin{array}{c}\text { Topsoil }(0-30 \mathrm{~cm}) \\
\text { S6 }\end{array}$} & $\begin{array}{l}\text { Aluminosilicate }+++ \\
\text { Ca carbonate }++ \\
\text { Native sulphur +; } \mathrm{C}_{\text {org }} \text { aggregate +; Fe oxide +; Quartz +; Illite +; Dolomite +; Na, } \\
\text { K feldspar + } \\
\text { Fe oxide with Cr I; Ca sulphate I; Chlorite I; Muscovite I; } \\
\text { Ca phosphate I; Zn sulphate I }\end{array}$ \\
\hline \multirow{4}{*}{ 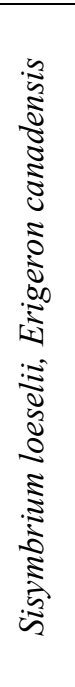 } & Root & $\begin{array}{l}\text { Quartz +++; Ba sulphate }+++ \text {; Aluminosilicate }+++ \\
\text { Dolomite }++ \\
\text { Kaolinite +; Ca carbonate +; Fe oxide }+ \\
\text { Muscovite I; Chlorite I; Ca phosphate I; Pb-Sn alloys I }\end{array}$ \\
\hline & Stem & $\begin{array}{l}\text { Quartz }+++; \text { Fe oxide }+++ \\
\text { Ca sulphate }++ \text {; Na chloride }++ \\
\text { K chloride+; K feldspar }+ \\
\text { Kaolinite I; Biotite I; } \mathrm{Cu}, \mathrm{Zn} \text { sulphate I }\end{array}$ \\
\hline & Leaf & $\begin{array}{l}\text { Quartz +++; Aluminosilicate +++ } \\
\text { Na chloride }++ \text {; Ca sulphate }++ \\
\text { K chloride }+ \\
\text { Fe, Cr oxide I, Dolomite I; Muscovite I; Au-Cu-Ag alloys I; } \\
\text { Ca carbonate with P and Mn I; Ba sulphate I }\end{array}$ \\
\hline & Flower & $\begin{array}{l}\text { Quartz }+++ \text {; Aluminosilicate }+++ \\
\text { Dolomite }++ \\
\text { Ca carbonate }+ \text {; Muscovite }+ \\
\text { Fe oxide I; } \mathrm{Au}-\mathrm{Cu} \text { alloys I; } \mathrm{Pb}-\mathrm{Sn} \text { alloys I }\end{array}$ \\
\hline
\end{tabular}

\section{DISCUSSION}

Municipal dumps are very rarely reclaimed using material rich in organic matter. This occurs in coalmining areas where mine waste is plentiful. Organic matter in the topsoil layer is represented by macerals from the vitrinite-, secondary inertinite- and liptinite groups. Macerals from the vitrinite group are especially prone to self-heating (Ciesielczuk et al., 2014). TOC contents in the studied topsoil are such that, under appropriate conditions, self-heating can occur. On the investigated dump, combustion occurred in the reclamation layer.

Local temperature increases to ca $460{ }^{\circ} \mathrm{C}$ (Ciesielczuk et al., 2011) led to chemical transformations in the topsoils. The main mineral components, i.e., aluminosilicates, quartz, chlorite, muscovite, and Fe sulphides (Table 1) are identical to those found in Mississippian rocks, the source of the material used for reclamation. At a stage of secondary alteration, also under the influence of heat, $\mathrm{Ca}$ sulphates (Figs. 3c, e) and Fe sulphates (Figs. 3a, 4b) originate, and also native sulphur (Figs. 2, 3d, d', 4c). The source of primary sulphur is pyrite present in the Mississippian rocks. Exothermic pyrite alterations lead to the formation of phases rich in sulphur. The presence of native sulphur reflects reduction from solutions rich in $\mathrm{SO}_{4}{ }^{2-}$. The formation of native sulphur was probably stimulated by mesophilic bacteria (Xu et al., 2013).

Comparison of soil compositions based on the XRD results shows that all of the samples studied have very similar compositions. Differences are obvious only by reference to the significant proportion of native sulphur and gypsum in samples 4 and 5 (Fig. 2). 
Table 2 HM content in soil and dry plant mass PS1- Sisymbrium loeselii from S1 site, PAm1-Amaranthus retroflexus from S1 site, PAm4- Amaranthus retroflexus from S4 site, PE4- Erigeron canadensis from S4 site, PAr5- Artemisia vulgaris form S5 site, PS6- Sisymbrium loeselii from S6 site, PC- Cucurbita pepo.

\begin{tabular}{|c|c|c|c|c|c|c|}
\hline \multirow{2}{*}{ Sample } & \multicolumn{6}{|c|}{ Element $\left[\mathrm{mg} \mathrm{kg}^{-1}\right]$} \\
\hline & Zn & $\mathbf{P b}$ & Mn & $\mathbf{C u}$ & $\mathbf{N i}$ & Cd \\
\hline S1 & 1770 & 739 & 281 & 303 & 41 & 6 \\
\hline S2 & 720 & 294 & 161 & 205 & 23 & 3 \\
\hline S3 & 1963 & 684 & 501 & 323 & 78 & 8 \\
\hline S4 & 263 & 222 & 73 & 131 & 17 & 1 \\
\hline S5 & 1982 & 587 & 443 & 283 & 46 & 7 \\
\hline S6 & 1688 & 509 & 527 & 302 & 37 & 5 \\
\hline PS1/leaf & 84 & 1 & 15 & 4 & $<1$ & $<1$ \\
\hline PS1/root & 250 & 41 & 65 & 30 & 3 & 1 \\
\hline PAm1/root & 190 & 13 & 52 & 14 & 2 & $<1$ \\
\hline PAm4/root & 129 & 5 & 34 & 7 & 2 & $<1$ \\
\hline PE4/root & 205 & 40 & 60 & 29 & 4 & 1 \\
\hline PAr5/root & 284 & 59 & 30 & 50 & 4 & 1 \\
\hline PS6/root & 74 & 12 & 12 & 11 & 4 & 0 \\
\hline PC/pulp & 50 & 3 & 5 & 12 & 1 & 0 \\
\hline PC/seed & 145 & 1 & 19 & 14 & $<1$ & 1 \\
\hline
\end{tabular}

Barite grains (Fig. 3b) and numerous $\mathrm{Fe}$ oxides/hydroxides (Figs. 3 c, f) are characteristic of the soils. In SEM images, submicroscopic grains of $\mathrm{Pb}$ sulphides (Fig. 3e) and $\mathrm{Au}-\mathrm{Cu}$ compounds indicate that novel phases formed during pyrolysis. Grains of heavy metals $<10 \mu \mathrm{m}$ in size were identified in topsoil and on plant roots, leaves and flowers. Grains of alloys such as $\mathrm{Au}-\mathrm{Cu}(<3 \mu \mathrm{m})$, Au-Cu-Ag $(<4 \mu \mathrm{m})$ and $\mathrm{Pb}-\mathrm{Sn}(<13 \mu \mathrm{m})$ point to the occurrence of metallic components in PM2.5 dust from local industrial emissions; in the vicinity of metalprocessing factories, these likely involved particles with $\mathrm{Cu}, \mathrm{Ag}, \mathrm{Au}, \mathrm{Pb}$ and $\mathrm{Sn}$. Iron oxide- and aluminosilicate aggregates on roots also commonly contain Zn (Figs. 5b, c).

BSE images showing the epidermis of roots, stems, leaves and flowers indicate that the finest $(<2 \mu \mathrm{m})$ mineral grains containing heavy metals are often in epidermal cavities and fractures. The surface structure also favors attachment of grains coming from atmospheric emission. Silification processes observed on E.canadensis leaves (Fig. 5a) shows that geochemical activity in the biotic zone (on flower surfaces) is significant; in this case, new secondary silica developed. It is very interesting that plants, on which secondary silica formed, were growing close to self-heating sites. This preliminary study cannot demonstrate any explicit dependence between the silica growth and the heating.

Significant quantities of $\mathrm{Ca}-, \mathrm{Fe}-$ and $\mathrm{Zn}$ sulphates in the topsoil on the dump reflect the leaching of metals from primary minerals and are indicative of acid-waste drainage processes (Sracek et al., 2004). The presence of $\mathrm{Na}-$ and $\mathrm{K}$ salts, and of gypsum, on leaves and stems indicates that crystalline salts formed by processes linked with water transpiration.

The heavy-metal (e.g., $\mathrm{Zn}, \mathrm{Pb}, \mathrm{Mn}, \mathrm{Cu}, \mathrm{Ni}, \mathrm{Cd}$ ) contents in the waste derived from different Mississippian rocks are similar to the quantities in rocks exploited in Polish coal mines (Bzowski and Michalik, 2015). Contents are higher in the finest fraction. In the finest fractions, metalliferous grains typically range from 1-100 $\mu \mathrm{m}$. In plants growing on the dump, heavy-metal contents approximate to the average for industrial regions in southern Poland (Kabata-Pendias, 2001). These processes can be strongly stimulated by raised temperatures in selfheating zones. In areas of self-heating the $\mathrm{pH}$ differences that span the wide range from 3.74-8.02 may reflect the variable properties of the material used in reclamation.

\section{CONCLUSIONS}

On dumps reclaimed by coal wastes containing high $(>10 \%)$ contents of organic matter, self-heating centers tend to develop. In these places, the conditions of secondary alteration of minerals occurring in soils are changed. The conditions for plant growth are also different, which may be important in any consideration of dump-surface phytoremediation. 
1. Pyrolysis favours some chemical transformations, e.g., the formation of dehydrated $\mathrm{Ca}, \mathrm{Fe}$ sulphates, submicroscopic sulphur, and $\mathrm{Fe}$ oxides/hydroxides.

2. The occurrence of submicroscopic $(<13 \mu \mathrm{m}) \mathrm{Au}-$ $\mathrm{Cu}, \mathrm{Au}-\mathrm{Cu}-\mathrm{Ag}$, and $\mathrm{Pb}-\mathrm{Sn}$ grains can be the result of thermal alteration involving self-heating processes. These also favour silification of leaf tissues, e.g. E.canadensis.

3. On plant shoots, salts such as $\mathrm{NaCl}$ and $\mathrm{KCl}$ may occur as a consequence of transpiration processes and the salinity of waters present in the Mississippian rocks are used for reclamation.

4. Some heavy-metal concentration levels are relatively high, e.g, $\mathrm{Zn}\left(263-1982 \mathrm{mg} \mathrm{kg}^{-1}\right)$ and $\mathrm{Pb}$ (222-739 $\left.\mathrm{mg} \mathrm{kg}^{-1}\right)$. However, this is not connected with the Mississippian material used for reclamation, but with industrial sources. High contents of $\mathrm{Zn}$ and $\mathrm{Pb}$ are characteristic for soils and anthrosols in the USCB region. The results indicate that there is a positive correlation in metal contents between the soils highly enriched in heavy metals and the plants growing on them.

5. The use of material containing pyrite or other reactive sulphides for the reclamation of dump surfaces is not advisable from an environmental point of view because acid-waste drainage processes can develope both on a macro- and/or microscale.

\section{ACKNOWLEDGMENTS}

The authors gratefully thank the anonymous reviewers for their critical and constructive comments. We thank Dr. Padhraig S. Kennan (University College Dublin, Ireland) for his help in improving the English of this paper.

\section{REFERENCES}

Bzowski, Z. and Michalik, B.: 2015, Mineral composition and heavy metal contamination of sediments originating from radium rich formation water. Chemosphere, 122, 79-87.

DOI: 10.1016/j.chemosphere.2014.10.077

Cabala, J., Smieja-Król, B., Jablonska, M., and Chrost, L.: 2013, Mineral components in a peat deposit: looking for signs of early mining and smelting activities in Silesia-Cracow region (Southern Poland). Environmental Earth Sciences, 69(8), 25592568. DOI: $10.1007 / \mathrm{s} 12665-012-2080-6$

Ciesielczuk, J., Czylok, A. and Cebulak, S.: 2011, Plant succession and gigantism observed on the burning coal waste dump in Katowice-Wełnowiec, Poland. Documenta Geonica, 1, 51-54.

Ciesielczuk, J., Misz-Kennan, M., Hower, J.C. and Fabiańska, M.J.: 2014, Mineralogy and geochemistry of coal wastes from the Starzykowiec coal-waste dump (Upper Silesia, Poland). International Journal of Coal Geology, 127, 42-55.

DOI: 10.1016/j.coal.2014.02.007

Cui, B., Zhang, Q., Zhang, K., Liu, X. and Zhang, H.: 2011, Analyzing trophic transfer of heavy metals for food webs in the newly-formed wetlands of the Yellow
River Delta, China. Environmental Pollution, 159, 1297-1306. DOI: 10.1016/j.envpol.2011.01.024

Fabiańska, M.J., Ciesielczuk, J., Kruszewski, Ł., MiszKennan, M., Blake, D.R., Stracher, G. and Moszumańska, I.: 2013, Gaseous compounds and efflorescences generated in self-heating coal-waste dumps - A case study from the Upper and Lower Silesian Coal Basins (Poland). International Journal of Coal Geology, 116-117, 247-261.

DOI: $10.1016 /$ j.coal.2013.05.002

Galos, K. and Szlugaj, J.: 2014, Management of hard coal mining and processing wastes in Poland. Mineral Resources Management, 30(4), 51-64.

Jerzykowska, I., Majzlan, J., Michalik, M., Göttlicher, J., Steininger, R., Błachowski, A. and Ruebenbauer, K.: 2014, Mineralogy and speciation of $\mathrm{Zn}$ and As in Feoxide-clay aggregates in the mining waste at the MVT $\mathrm{Zn}-\mathrm{Pb}$ deposits near Olkusz, Poland. Chemie der Erde, 74, 393-406.

DOI: $10.1016 /$ j.chemer.2014.03.003

Kabata-Pendias, A.: 2001, Trace Elements in Soil and Plants, 3nd Edition, CRC Press, $413 \mathrm{pp}$.

Kędzior, S. and Jelonek, I.: 2013, Reservoir parameters and maceral composition of coal in different Carboniferous lithostratigraphical series of the Upper Silesian Coal Basin, Poland. International Journal of Coal Geology, 11, 98-105.

DOI: $10.1016 /$ j.coal.2012.08.007

Klejnowska, H.: 1996, Building project: Development of greenery and parks of municipal waste dump area in Katowice at Ludwika-Leopolda Street . I and II stage (sealing and degassing of sector "C"), EKOTEST s.c., Gliwice, (in Polish).

Misz-Kennan, M. and Fabiańska, M.: 2010, Thermal transformation of organic matter in coal waste from Rymer Cones (Upper Silesian Coal Basin, Poland). International Journal of Coal Geology, 81(4), 343358. DOI: $10.1016 /$ j.coal.2009.08.009

Nagajyoti P.C., Lee, K.D. and Sreekanth, T.V.M.: 2010, Heavy metals, occurrence and toxicity for plants: a review. Environmental Chemistry Letters, 8(3), 199216. DOI: $10.1007 / \mathrm{s} 10311-010-0297-8$

Sracek, O., Choquette, M., Gélinas, P., Lefebvre, R. and Nicholson, R.V.: 2004, Geochemical characterization of acid mine drainage from a waste rock pile, Mine Doyon, Québec, Canada. Journal of Contaminant Hydrology, 69(1-2), 45-71.

DOI: 10.1016/S0169-7722(03)00150-5

Stracher, G.B., Prakash, A. and Sokol, E.V.: 2015, Coal and Peat Fires: A Global Perspective, 3, Case Studies Coal Fires. Elsevier B.V.

Szczygieł, A., Szumowska, A. and Pillich-Konieczny, A. (Eds.): 2013, Conditions of environment in Silesian Voivodeship in a year 2012. Voivodeship Environmental Protection Agency. Special Report. Katowice, (in Polish).

http://www.katowice.pios.gov.pl/monitoring/raporty/2 012/raport2012.pdf

Taylor, G.H., Teichmüller, M., Davis, A., Diessel, C.F.K., Littke, R. and Robert, R.: 1998, Organic Petrology. Gebrüder Borntraeger, Berlin. 704 pp.

Xu, X., Chen, Ch., Lee, D-J., Wang, A., Guo, W., Zhou, X., Guo, H., Yuan, Y., Ren, N. and Chang, J-S.: 2013, Sulfate-reduction, sulfide-oxidation and elemental sulfur bioreduction process: Modeling and experimental validation. Bioresource Technology, 147, 202-211. DOI: 10.1016/j.biortech.2013.07.113 